\title{
EFFORTS TO SURVIVE IN SCOTT NEUSTADTER'S AND MICHAEL H. WEBER'S MOVIE SCRIPT THE FAULT IN OUR STARS
}

\author{
Fakhira, Zulfan Sahri \\ Universitas Islam Sumatera Utara, Medan, Indonesia \\ e-mail: fakhirayustin11@gmail.com
}

Received: 2021-10-01

Accepted: 2021-11-14

\begin{abstract}
This paper deals with the Effort to Survive in Scott Neustadter's and Michael H. Weber's movie script The Fault In Our Stars, and it refers to two topics of discussion i.e. pleasing herself and doing medication ; the protagonist's effort to stay alive is due to suffering from stage 4 thyroid cancer. In analyzing the two topics, the descriptive qualitative method is taken as most appropriate method to process the data. The analysis indicates that the protagonist encouragingly makes some efforts for her healthy treatments as to please herself involving meeting her lover, going for a picnic, and meeting her favorite author; as to do medication by doing some therapies and joining support group. The results shows that the protagonist has attempted so hard to survive by doing things for her recovery; her cancer disease needs to have psychological treatment that can please herself and by doing medical treatment, medical therapies to cure a rare form of cancer. All of these are the protagonist's efforts to live her life longer.
\end{abstract}

Keywords: survive, medication, movie script, effort

\section{Introduction}

The Fault in Our Stars is an American romantic film in 2014. It is directed by Josh Boone and produced by Marty Bowen and Wyck Godfrey. The script for the film is written by Scott Neustadter and Michael H. Weber based on John Green's novel The Fault in Our Stars. Eric Scott Neustadter is born in Margate City, New Jersey on 1977. $\mathrm{He}$ is an American screenwriter and producer. At age 25, Neustadter moved to study in Los Angeles, California and shortly thereafter moved to Santa Monica, where he currently resides. He often works with his writing partner, Michael H.Weber (Kaufman. 2008; wikiwand, 2021).

Weber is born in Great Neck, New York on January 13, 1978. He attended Syracuse University and graduated in 2000. Weber met his writing partner Scott Neustadter in 1999 at TriBeCa Productions when Neustadter hired Weber as his development intern. They started writing comedy together in their spare time, and soon after beginning writing a screenplay based on a failed relationship that Neustadter had experienced. When Weber and Neustadter heard that 20th Century Fox had purchased the rights to adapt The Fault in Our Stars a young adult novel written by John Green, about the romantic relationship between two teenagers with cancer into a film, they campaigned the company's president to hire them to write the screenplay (Kaufman. 2008; wikiwand, 2021). 
The Fault in Our Stars tells about a teenager Hazel, who suffers from stage 4 thyroid cancer and always saw carrying an oxygen tank with a cannula on her nose for her to breathe. In order to survive, she does some efforts that can please herself and medical treatment. One of her efforts is doing some therapy and medication to cure her illness. She is also urged by her mother to attend a weekly cancer patient support group. Her mother hopes that Hazel's depression due to her illness can be relieved by attending the group. When she is attending the support group, she meets her lover, Augustus Waters, an osteosarcoma patient. They have the same hobby; both like reading books. Meeting her lover is a form of Hazel's efforts in living life. With the presence of Augustus (Gus), Hazel becomes more excited to live her life. Pleasing herself is also an effort in living life. Hazel wants to do things she had never done before. She decides to go for a picnic with Gus. They spend time together until the evening.

The major themes in the movie script that create much interest are pleasing herself and having some medications. Pleasing yourself is necessary in life and it is one way to survive. Pleasing yourself by enjoying the little pleasures in life without regretting oneself will make yourself also need to be happy. Another way to survive in life is by doing some medical treatment. The protagonist suffers from the thyroid cancer and does some effort to survive for the rest of her life.

\section{Literature Review}

Every human being, living on this earth, must make every effort for his/her life. Effort is an activity that exerts energy and thought to achieve goals. People make effort individually or collectively to lift heavy weights, to achieve dreams or desires, to concentrate, to solve problems, to convince others, or to earn money. All of these things can be used as the reasons for someone to do efforts. By making efforts, humans can also get what they want. According to Surayin (2001: 665), effort is an attempt to achieve a purpose. Every effort aims to prevent something that is deemed unnecessary or disturbing so that we can find a way out.

According to Massin $(2017,16)$, in his journal, effort can be explained as a primitive feelings and action. He also states that effort contains mental episodes which do not indicate anything. Effort may also refer to the category of feelings that can be compiled together with pains, tickles, and nausea. On the other hand, this primitive feeling can be viwed as the effort that belongs to the category of actions, not of feelings. Then, Massin (2017) classifies effort into six types as set out in the following:

1. Feelings are episodes. People have a feeling of pain, or a strong feeling for some persons. Meanwhile, efforts are made by us; we have feelings, but make efforts.

2. Second, efforts have many given purposes that feelings lack. Efforts are necessarily related to a goal, which its complete point is intended to reach, while feelings do not show such goal-directedness. This can be seen from at least two ways. First, someone may confirm that feelings have adaptive value - feelings do not definitely wish for something. Second, someone may think that feelings, such as the feeling of pain, call for some reaction - for example, pain should be avoided. Efforts do not in any sense call for the pursuit of an end: they are pursuits of ends.

3. Efforts are productive. One can lift weights, convince people or solve equations. One cannot do these things with feelings although feelings certainly do have other sorts of influences on our behavior. 
4. Efforts have success conditions. When an effort achieves the goal it aims at, it is successful. If it does not achieve the goal, it is a failure. Feelings by contrast have no success conditions. However, feelings have accuracy conditions which efforts lack. Efforts cannot be veridical; feelings cannot be successful.

5. Efforts typically are accompanied by some resistance, which the agent tries to overcome. Things resist our efforts, but they do not resist our feelings.

6. The case of efforts is, under certain conditions, not clearly the case of feelings. When one praises a student for his efforts, we do not praise him for his feeling.

Efforts are primarily not feelings, in the same way that hardness, hotness, or pains are. Then, efforts, therefore, should be differentiated from feelings. Even if efforts are not feelings but actions, perhaps one of their essential components - their difficulty or unpleasantness - is necessarily felt (Massin (2017, 16-17).

Referring to some understanding of effort above, effort is made to solve a problem and to achieve the expected goals. The word "effort" is a noun which has meaning "a serious attempt" or "conscious exertion of power or hard work". Effort can also be interpreted as a means or work that we make towards an activity. However, in doing some activity, everyone has problems in their life. As Kleinbaum and Klein (1996: 480) quoted from Braun, Linder and Asimov, they clarify that everyone always has problems in their life. Problems can be simple or difficult. Sometimes, they influence their problems. They then clarify an example to the condition of patients that resembles that of in The Fault in Our Stars. Kleinbaum and Klein (1996: 481) describe "a survival data in a study in which patients receiving radiotherapy for head and neck cancer may either die from their cancer or from some other cause of death. If all competing risks in a given study are different causes of death, then it is possible to have both competing risks and recurrent events in the same study."

Furthermore, survival is derived from the word 'to survive' which means endurance or life support. Survive may also mean to maintain life. Anyhow, everyone who lives must have a strategy in his life. Meanwhile, 'survive' needs to be linked with the term 'strategy' to enable us to bring it into research or study. Survival strategy is a way to defend themselves so that humans can continue their lives. A survival strategy is a plan of action or activities carried out in order to survive in any situation. Strategy can be said as a plan that is built to achieve goals. According to Suharto (2009), in general, survival strategies can be defined as "a person's ability to apply ways to overcome various problems that interfere with life."

It can be taken into account that the effort to survive is an activity or action which is carried out by a person with the aim of overcoming the problems that exist in his life, so that he/she can survive to continue his life. As depicted in the movie script, the protagonist survives owing to her eagerness to do psychological therapies as pleasing herself, and to have some medical treatments. In this respect, the psychological aspects is also applicable to analyze 'effort to survive' from literary psychology theory.

Literary psychology is a branch of literature that is used to approach (study) a literary work from a psychological perspective (Noor, 2004: 92). According to Hardjana (1985), the literary psychology approach is as a way of doing analysis based on psychological point of view, and starts from the assumption that literary works always discuss human life events as the reflections of living and responding to life. Here, the function of psychology itself is to make exploration into the inner soul carried out by 
characters in literary works and to find out more about the intricacies of human actions and their responses to other actions.

Related to psychology, literature is an interesting study material, because literature is not just a tedious study of texts, but becomes a study material that involves the characterization or personality of characters in literary works (Minderop, 2005). Much of the behavior of humans and the activities they carry out can be explored by the psychological disciplines. To understand the various psychological forms experienced by characters in a literary work, a researcher can relate it with literary psychology. Literary psychology is a study that examines the psychological reflections in characters presented in such a way by the author, so that readers feel lulled by the psychological problems contained in literary works (Minderop, 2005).

\section{Research Method}

This paper is designed from the data encountered in movie script The Fault in Our Stars that shows the protagonist's effort to survive due to having thyroid cancer. It then takes Massin's (2017) distinction to 'effort'as a physical or mental activity required to reach something, and Suharto's (2009) description to 'survive' as the way to continue to live after coming close to dying. Descriptive research method is provided for processing and analysing the data, and this is related to what Bogdan and Biklen (2012) say, "qualitative is descriptive, where data are in the form of words or picture rather than numbers." The expression through words and picture is mainly the key to understand that the words in script can be made as the data analysis. The data are chiefly taken from the movie script and the others are from reference books containing some theories, opinions, or arguments related to the subject matter of the discussion. The analysis covers two major points i.e. pleasing herself pertaining to meeting her lover, going for a picnic, and meeting her favourite author, and doing some medication in line with doing some therapies and joining support group. To make the analysis running as expected, the whole data from the script are classified based on the points, and are organized and analyzed respectively.

\section{Discussion}

The discussion covers the protagonist's efforts to survive including pleasing herself i.e. meeting her lover, going for a picnic, and meeting her favorite author, and doing some medication i.e. doing some therapies and joining support group, as described the following sub-sections:

\subsection{Pleasing Herself}

\subsubsection{Meeting Her Lover}

Accidental meeting between man a woman often grows love, and this happens to Hazel, the protagonist, and Gus. Hazel, never thinks of any man that may fall in love with her anymore since she is diagnosed to have thyroid cancer. The reason is that she always feels that her life does not take a long time; the cancer has created depression in her mind and soul. However, when her doctor tells her to follow the support group to relieve her depression, there she meets a man who later becomes her lover.

$\begin{array}{ll}\text { GUS } & \text { Ooph. } \\ \text { HAZEL } & \text { : Sorry! }\end{array}$


A SUPREMELY BEAUTIFUL BOY (we will come to know him as Gus). Tall, lean, muscular, straight short mahogany hair, blue eyes. Hazel has never seen a better looking kid in her life.

GUS : My bad. No, it's ...

For a brief moment, the Earth stop. They stand looking at one another. Hazel is speechless.

HAZEL : Excuse me.

(Neustadter and Weber, 2014: 9)

The quotation above illustrates that Hazel accidentally nudges a boy when walking in front of the support group center; the boy looks taller than her. Anyhow, Hazel feels that she has never seen the boy in the group before. For a moment, they are standing and looking at one another, but Hazel does not try to talk to him. On the other hand, Hazel decides to leave that boy. Hazel shuffles off as fast as she can and go to the hall. The boy with a wan smile on his face continues to stare at Hazel who is moving away from him. Hazel's meeting with him is portrayed in the quotation below.

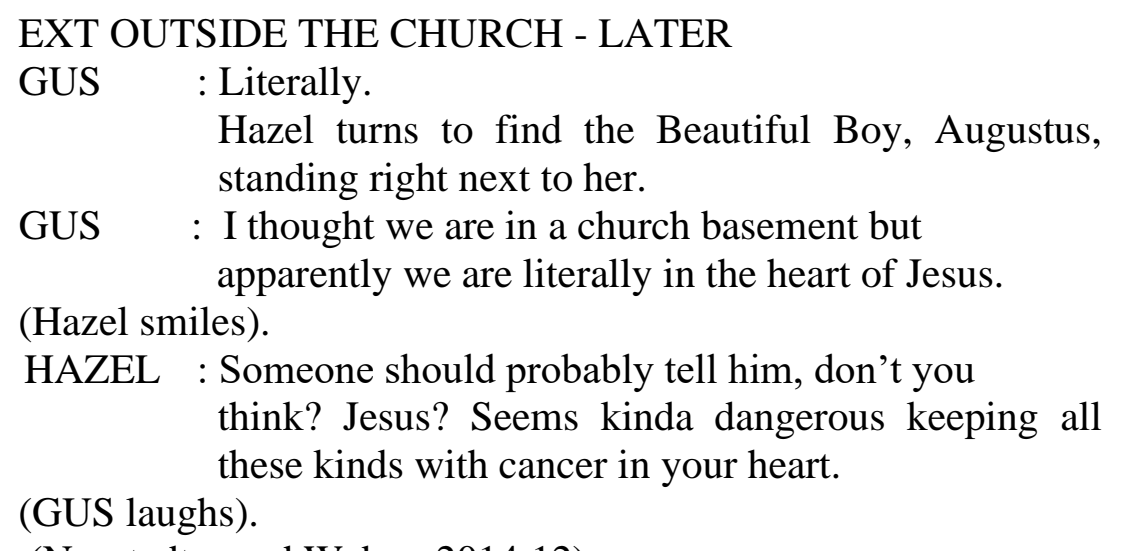

(Neustadter and Weber, 2014:12)

The data above verifies that Hazel is waiting for her mother to pick her up from the support group. When she is talking to her mother outside the church, Hazel is quite surprised because she suddenly hears someone talking towards her. She finds out where the voice is coming from; in fact, the voice is from the boy standing right next to her. $\mathrm{He}$ is Augustus Waters, a boy who later becomes her boyfriend. His eagerness to know her is so strong that he happily introduces himself to Hazel. His presence in her life creates very much pleasure to her.

GUS : What's your name?

HAZEL : Hazel.

GUS : No your full name?

HAZEL : (confused) Hazel Grace Lancaster.

Gus nods to himself, smiles. Still fixated on her.

HAZEL : What?

GUS : I didn't say anything.

HAZEL : Why are you looking at me like that?

GUS : Because you're beautiful.

Hazel is taken aback. No one's ever said that to her before. 


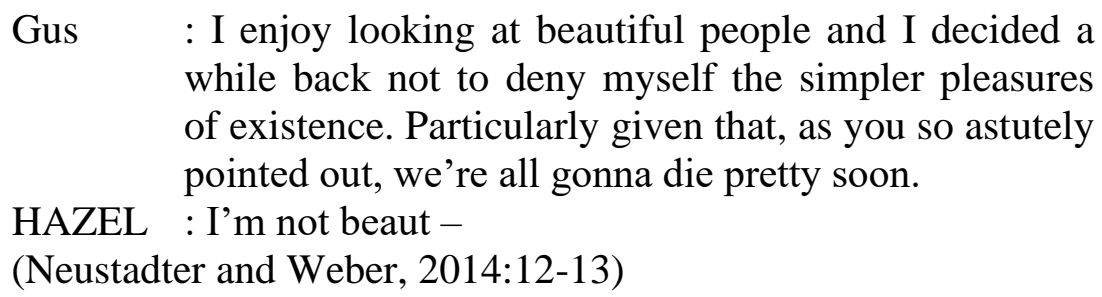

It seems that Hazel and Gus get to know each other. Surprisingly, when they are talking, Gus cannot stop looking at Hazel, and certainly, Hazel feels strange with Gus' attitude - always keeping her smile at her. It reveals that Hazel is a quite beautiful girl, Gus' simple pleasure is just to enjoy seeing anice girl in front of him. However, Hazel feels that she never stand for regarding herself as a beautiful girl because there are many girls in the support group who are more beautiful than her.

\subsubsection{Going for a Picnic}

The idea to go for a picnic comes from Gus. He regards that this way can arise Hazel's desire to please herself. Gus, therefore, invites her to spend their time together in a certain place. By taking her for a walk, it may reduce her burden for not just thinking about her harmful disease. Even then, it will bring about pleasure for both of them. He really hopes that it will embetter Hazel's feeling. For him, Hazel may calm down her worriness especially when she is going back from the hospital. Her happiness amazingly appears at the time she agrees with his offer, as indicated in the quotation below.

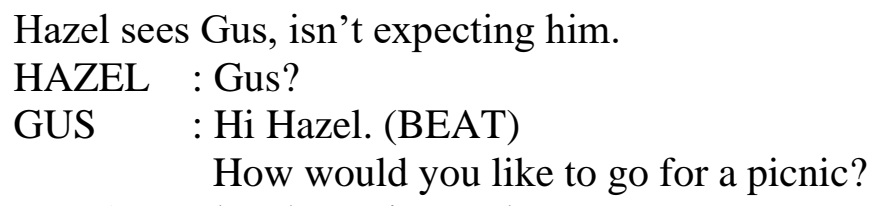

HAZEL laughs. Point made.

(Neustadter and Weber, 2014: 38)

This conversation happens in Hazel's house after Hazel and her parents return home from the hospital. Whatever Gus does is just to please Hazel. That is why he earnestly asks Hazel to enjoy the time. Gus believes that Hazel may relieve her depression, and he also knows that Hazel wants to do something she has never done before in the rest of her life. Fortunately, everything he has planned runs as he expected. Hazel enjoys every single part on that day without thinking about her condition.

He grabs her hand, helps her walk up a tiny hill. Once up there, GUS lays a blanket on the ground. They sit, looking out over a rather odd SCULPTURE - a set of GIANT WHITE BONES where children can jump and play.

(Neustadter and Weber, 2014: 40)

They certainly spends their time in a small hill. Hazel, who always carries her oxygen everywhere, is helped by Gus to climb it up. They sit on the ground and see children playing happily without having felt any pain like them. Like a normal person Hazel enjoys a beautiful day together. Hazel forgets the fact that she is living the rest of her life. It is unlikely that Hazel would ever recover from her illness. Thereore, it seems 
that going somewhere becomes a nice and good way to bring happiness as what Gus and Hazel have done.

\subsubsection{Meeting with Her Favorite Author}

It starts when Hazel talks about her favorite novel to Gus. The title of the novel is "An Imperial Affliction “written by Hazel's favorite author, Peter Van Houtten. The story of the novel is about cancer and Hazel feels the story is like what she feels right now. Hazel and Gus swap their favorite novels each other. Gus reads the novel and agrees with Hazel that they need an ending. Gus does something to please Hazel once again. Gus then tries to make her realize that he also has an interest to meet the author. In this respect, by meeting her favorite author is another way to please her, and this matter is clearly portrayed in the following:

She starts to realize.

$\begin{array}{ll}\text { Hazel } & \text { : Are you saying- } \\ \text { GUS } & \text { : I'm not gonna give you my wish or anything. But I } \\ & \text { too have an interest in meeting Peter Van Houten and } \\ & \text { it wouldn't make much sense to meet him without the } \\ \text { girl who introduced me to his book, now would it? } \\ \text { (Hazel's eyes widen). } \\ \text { I talked to the Genies and they're in total agreement. } \\ \text { (Beat) We leave on May third. }\end{array}$

(Neustadter and Weber, 2014: 42)

Gus finds it unreasonable to go to meet the author, Van Houten, without Hazel who has introduced him about the novel. Gus also knows that Van Houten is Hazel's favorite author. Hazel widens her eyes indicating that she is surprised to hear Gus' words and she thanks Gus for bringing her together to the author. They decide to meet the author early in May. Hazel's meeting with the author is set out in the following quotation.

EXT. VONDELSTRAAT ROW HOUSES - LATER.

Gus and Hazel stand outside Van Houten's white house.

HAZEL : I'm so excited I can barely breathe.

Gus : As opposed to other days...?

(Neustadter and Weber, 2014: 70)

Meeting a distinguished person is rather difficul. Hazel and Gus should stand outside Van Houten's white house before they are allowed to come in. Anyhow, in a moment after they enter the house, Hazel acknowledges that she is very excited to meet him. This is like a dream for her. Hazel is quite happy to see him for the first time, and she never imagines that her meeting with him finally comes true. This is positively pleasing her heart as she shows it clearly in her words that she can barely breathe - it, therefore, becomes her sincere and straightforward expression.

\subsection{Having Medication}

\subsubsection{Doing some Therapies}

Hazel has been diagnosed to have cancer since she was 13 years old. She has a biopsy - a stage IV thyroid cancer. With such a condition, there is a quite small 
Efforts to Survive in Scott Neustadter's and Michael H. Weber's Movie Script The Fault In Our Stars, Fakhira, Zulfan Sahri

possibility for her to recover from this illness. However, Hazel still insists on getting some medication through radiation and chemotherapy.

This poor little girl is taking a beating. And it's just getting

started.

HAZEL (V.O.) : Then radiation...

- Having her head shaved by Frannie.

HAZEL (V.O.) : Then Chemo...

-With a PICC line in a chemo chair.

(Neustadter and Weber, 2014:17)

Hazel must have some medication for her recovery. The medical therapies that are familiarly done are by having radiation and chemo in her body. Normally, radiation is given through x-ray exposure, and it often relates with chemotherapy and surgical removal of the cancer. The ways how she gets the therapies are shown in the following.

Frannie : (through the tears). Are you ready, sweetie?

14-Year Old Hazel nods. Michael can't keep it together any

longer. He completely breaks down.

HAZEL (V.O.) : But it isn't.

INT ICU - THE NEXT MORNING

The sun shines in the room. 14-year old Hazel eats ice chips, the color has returned to her cheeks.

HAZEL (V.O) : The antibiotics kicked in. They drained the fluid from my lungs. And in time I got better.

Stronger.

(Neustadter and Weber, 2014: 18)

Hazel is in the ICU and the therapy is done. At this time, Hazel struggles to breathe though her lungs are started filling up with water. In the next morning, the surgery is claimed to be successful. The radiologist has drained the fluid from Hazel's lungs. Hazel becomes better and stronger. Though Hazel believes that it is just an experimental trial, and works for a while, yet the radiologist states that, after he looks at an X-ray, this is a miracle for her to get safe from such a therapy.This miracle is depicted in the quotation below.

INT YET ANOTHER HOSPITAL ROOM - DAY

Slightly older Hazel is getting more intraveneous medicaton. It's never ending.

HAZEL (V.O.) : I even found myself in an experimental trial. You know the ones that are famous in the Republic of Cancervania for not working.

-A SECOND RADIOLOGIST examines a second X-ray.

HAZEL (V.O.) : It's called Phalanxifor. Didn't work in over 70 percent of patients but, for some reason...

The Radiologist looks surprised.

HAZEL (V.O.) $\quad: \ldots$ it worked in me. They called it

"The Miracle."

(Neustadter and Weber, 2014: 18) 
At the first time Hazel believes that the therapy will not give any good effect to her body because she knows well that it does not work effectively in over 70 percent of patient. Anyhow, the radiologist looks surprised to see the result and finds out that the cancer looks shrinking. In other words, he has succeeded to bring a new life to his patient. Knowing the result, Hazel expresses much thanks to him; she feels definitely satisfied with their resistant work. Her happiness and pleasure cannot be paid with anything else. Certainly from this moment, Hazel does not spend most of her time in the hospital except for doing some therapies and medical checkup for sometimes Hazel lungs are still suck, but she is sure that it will be quite fine for her in a while.

\subsubsection{Joining Support Group}

Since thyroid cancer infects her body, Hazel looks depressed; thus, Hazel is advised by her doctor to join a group of people with cancer. Hazel does not feel necessary to join the group, but the doctor and her mother do. Their advice to take part in support group is just for psychological treatment to maintain her strenght so that she will have power to face whatever may happen to her later.

DOCTOR : Have you been going to that Support Group,

$$
\text { I suggested? }
$$

Instead of answering, HAZEL looks at her mom.

FRANNIE : She's gone a few times.

HAZEL : I'm not sure it's for me.

DOCTOR : If you're depressed -

HAZEL : (EXASPERATED). I'm not de-

(Neustadter and Weber, 2014:3-4)

The Doctor deliberately spares his time to talk Hazel and Frannie, Hazel's mother. He suggests that following the group may become one of the ways to evade the depression, and therefore, she should join the support group. Hazel feels that joining the group will make her bored with stories of cancer patients. However, anyone who gets cancer as Hazel is often reluctant to accept that she is as depressed as the doctors told her. Hazel is not sure that the group could help her, but Frannie and the doctor suggest it anyway.

DOCTOR: (IGNORING HER) - Support Groups are a great way to connect with people who are...

HAZEL : What?

DOCTOR : (BEAT). On the same journey.

HAZEL : Journey? Really?

FRANNIE: Hazel.

DOCTOR : Just give it a chance, ok? For me.

Hazel rolls her eyes, know she's lost this battle.

DOCTOR: Who knows? You might even find it... enlightening.

(Neustadter and Weber, 2014: 4)

Hazel finally joins a support group that will provide her a healthy treatment. However, before she accepts the doctor's instruction, she feels slightly offended by the doctor's words. She rejects to be recommended to have the same journey with the people in the Support Group. Hazel thinks she is still fine without joining the group. In short, the doctor keeps asking her to take the opportunity in a support group. Her doctor 
expects that there will be an enlightenment for her if she is willing to join the group. Finally, with a great awareness, Hazel finally relents and follows what her doctor and mother suggest.

HAZEL : I'm, uh, Hazel.
(BEAT) Thyroid originally but with quite the
impressive satellite colony in my lungs.
Not much more to say, Hazel is about to sit down.
PATRICK : And how are you doing Hazel
Hazel has no idea how to answer that.
HAZEL (V.O.) : You mean besides the terminal cancer?
But that's not what she says. She says:
HAZEL : Alright? I guess...?
ALL IN UNISON: we're here for you Hazel.
Hazel exhales. This is not at all helpful. A few more beats
EXT CHURCH - LATER
Frannie sits in the car in the parking lot, reading from a book,
waiting for Group to be over. She sees the church door open and
puts the book away. Hazel comes out. Frannie looks at her like “
well, is it great? " Hazel just exhales and gets in the car.
(Neustadter and Weber, 2014: 5-6)

When she joins the support group, all she gets behind her expectation because the group is very unattractive for her. Hazel feels uninterested being in the group for she is chosen to share stories about her cancer. She finds it hard to tell them personally about her thyroid cancer. For her, it is not necessary to tell anyone about someone's disease. Consequently, to her disappointment, she deeply exhales because she gets nothing from the group. After the meeting ends, Hazel leaves the church and meets her mother in the parking lot. What her mother expects is not what Hazel feels. Her mother hopes everything would go well; meanwhile, Hazel argues that this group is not at all helpful, unlike what her doctor told her to do.

\section{Conclusion}

The analysis verifies that effort to survive in the movie script The Fault in Our Stars, which is categorized into two discussions i.e. pleasing herself and doing medication, can be noted as the protagonist's vigorous struggle to come to a new life after having been supposed to die a horrible death by the thyroid cancer. However, through her efforts guided by Gus, her boy friend; Frannie, her mother; and the doctor, Hazel's disease can finally be overcome, in spite of some further medical treatments that she should follow. Therefore, several things that hazel does for her recovery are to please herself such as meeting her lover, going for a picnic, and meeting her favorite author, and to do medical treatment such as taking some therapies and joining support group. Meeting her lover is identified from Hazel's loving to Augustus, going for picnic from Hazel's trip with Gus (Augustus), and meeting her favorite author from Hazel's travel to see Peter Van Houten. Besides, doing some therapies can be sought from the time when Hazel is set out for some medical recovery, and joining some support group from her attendance in the group. When the doctor firstly diagnoses that she has to live with the cancer for the rest of her life, she imagines that soon she will leave this world 
forever; however, when the doctor states that her cancer has been shrinking, she feels that she is still be able to live her life well.

\section{References}

Bogdan, Robert. C dan Sari Knopp Biklen. (2012). Qualitative Research for Education (Second Edition): An Introduction to the Theory and Methods. United States of America: Allyn and Bacon.

Hardjana, Andre. (1985). Kritik Sastra Sebuah Pengantar. Jakarta: Gramedia.

Kaufman, Anthony. (2008). Scott Neustadter and Michael H. Weber. 10 Screenwriters to Watch. Retrieved from https://variety.com/2008/film/markets-festivals/scottneustadter-michael-h-weber-1117987707/

Kleinbaum, D. G, and Klein, Mitchel (1996). Survival Analysis: A Self Learning Text. New York: Springer-Verlag

Massin, Olivier. (2017). Towards a Definition of Efforts. Retrived from https://www. academia.edu/32659503/Towards_a_Definition_of_Efforts

Minderop, Albertine. (2005). Metode Karakterisasi Telaah Fiksi. Jakarta: Yayasan Obor.

Neustadter, Scott and Weber, Michael H. (2012). The Fault In Our Stars. Retrived from https://imsdb.com/scripts/Fault-in-Our-Stars.

Noor, Redyanto. (2004). Pengantar Pengkajian Sastra. Semarang: Fasindo

Suharto, Edi. (2009). Membangun Masyarakat Memberdayakan Masyarakat. Bandung: PT Refika Aditama.

Surayin. (2001). Kamus Umum Bahasa Indonesia. Bandung: Yrama Widya

Wikiwand. (2021). Michael H. Weber. Retrived from https://www.wikiwand.com/en/ Michael_H._Weber 